\title{
In vitro Cellulose Rich Organic Material Degradation by Cellulolytic Streptomyces albospinus (MTCC 8768)
}

\author{
Pinky Prasad ${ }^{1}$, Sheila Bedi ${ }^{2}$ and Tanuja Singh ${ }^{3 *}$ \\ ${ }^{1}$ T-1, Kirti Apartment, P.O. Road, Shastri Nagar, Patna-800023, Bihar, India \\ ${ }^{2}$ Department of Botany, Patna Women's College, Patna University, Patna, Bihar, India \\ ${ }^{3}$ Department of Botany, B.M.D College, Dayalpur-844502, B.R.A Bihar, University, Bihar, INDIA \\ E.mail: tanujasinghpatna@yahoo.com
}

Received 19 September 2011; Received in revised form 9 April 2012; Accepted 12 April 2012

\begin{abstract}
Aims: Cellulosic biomass is the only foreseeable sustainable source of fuels and is also one of the dominating waste materials in nature resulting from human activities. Keeping in view the environmental problems like disposal of large volumes of cellulosic wastes and shortage of fossil fuel in the world, the main aim of the present investigation was to characterize and study the cellulolytic activity of Streptomyces albospinus (MTCC 8768), isolated from municipal wastes, on natural cellulosic substrates viz. straw powder, wood powder and finely grated vegetable peels.

Methodology and Result: Stanier's Basal broth with $100 \mathrm{mg}$ of each of the substrates was inoculated separately with S. albospinus (MTCC No. 8768) and incubated at $37^{\circ} \mathrm{C}$ for 8 days. The cellulosic substrates were re-weighed at an interval of 2 days and the difference between the initial weight and the final weight gave the amount of substrates degraded by the isolate. It was observed that maximum degradation was observed in the grated vegetable peels (64 $\mathrm{mg}$ ) followed by straw powder $(38 \mathrm{mg})$ and wood powder $(28 \mathrm{mg})$ over a period of 8 days.

Conclusion, significance and impact of study: By the selection of efficient cellulolytic microorganisms and costeffective operational techniques, the production of useful end products from the biodegradation of the low cost enormous stock of cellulose in nature can be very beneficial.
\end{abstract}

Keywords: Cellulolytic potential, cellulosic biomass, Streptomyces albospinus (MTCC 8768), sustainable fuel, waste material

\section{INTRODUCTION}

The cellulosic biomass, once thought to be an ever increasing unmanageable waste, is now considered as an important renewable source of energy. Despite being an abundant and low cost renewable organic matter in nature (Lynd et.al., 2002), cellulose can be utilized as a source of energy and for the production of useful end products only after its hydrolysis to glucose (Obuekwe and Okungbowa, 1986) which can further be used as a substrate for the other bioprocesses. By the selection of efficient cellulolytic microorganisms and cost-effective operational techniques, the production of such useful end products from the biodegradation of cellulose can be very beneficial. The importance of cellulose degradation and the use of its byproduct as a source of renewable energy is not a new thing. Cellulose may be hydrolyzed using cellulolytic enzymes to produce glucose, which can be used for the production of useful end products (Hao et al., 2006).

In this pretext, cellulolytic microorganisms play an important role in the biosphere by reducing cellulose (Gautam et al., 2010). To establish a successful fermentation process, it is necessary to make the microorganism for overproduction of the desired metabolite (Gautam et al., 2011). In this perspective, maintenance and enumeration of microbial diversity, especially of cellulose degraders, is beneficial in two broad ways. First, there is degradation of wastes and reduction of pollution of the environment for the betterment of the quality of life of human-beings and establishment of an eco-friendly environment for the generations to come. Secondly, the process of cellulose degradation results in the production of glucose that can be utilized as a source of food, feed and fuel. Since microorganisms are characterized by a very rapid growth, therefore, the process of microbial degradation of cellulose can be considered as financially viable and seems to be the wise choice. The present study on the screening and the biochemical analysis of bacteria isolated from the natural environment of Patna; has been carried out with the rationale to isolate a novel strain having significant cellulolytic potential to degrade different natural cellulosic wastes.

\section{MATERIALS AND METHODS}

\section{Chemicals}

Chemicals used for the preparation of the media were of the highest purity grade and purchased from the local market. The chemicals used were obtained from HiMedia, 
Loba Chemie, Merck and Qualigens.

\section{Media}

Media used during the course of the present investigation, unless otherwise mentioned, were sterilized by autoclaving at 15 p.s.i. for 15 min. Nutrient Agar (Peptone $5 \mathrm{~g} / \mathrm{L}$, beef extract $3 \mathrm{~g} / \mathrm{L}$, sodium chloride $5 \mathrm{~g} / \mathrm{L}$, agar 15 $\mathrm{g} / \mathrm{L})$ was used for isolation and preservation of cellulose degrader; Milk Agar, Methyl Red, Voges Proskauer broth, Nitrate broth, Phenol red dextrose broth, Phenol red lactose broth, Phenol red sucrose broth, Simmons Motility Agar, Simmons Motility Agar with tryptophan as substrate, Simmons citrate Agar, Starch Agar, Trypticase Soy Agar 87. and Urea broth were used for specific biochemical tests (Cappuccino \& Sherman, 2005). Stanier's basal medium $\left[\left(\mathrm{NH}_{4}\right)_{2} \mathrm{SO}_{4} 1 \mathrm{~g} / \mathrm{L}, \mathrm{K}_{2} \mathrm{HPO}_{4} 1 \mathrm{~g} / \mathrm{L}, \mathrm{MgSO}_{4} 0.2 \mathrm{~g} / \mathrm{L}\right.$, $\begin{array}{llllll}\mathrm{CaCl}_{2} & 0.1 \mathrm{~g} / \mathrm{L}, & \mathrm{FeCl}_{3} & 0.02 & \mathrm{~g} / \mathrm{L}] ; \quad \mathrm{CMC} \text { agar }\end{array}$ (carboxymethylcellulose $0.5 \mathrm{~g} / \mathrm{L}, \mathrm{NaNO}_{3} 0.1 \mathrm{~g} / \mathrm{L}, \mathrm{K}_{2} \mathrm{HPO}_{4}$ $0.1 \mathrm{~g} / \mathrm{L}, \mathrm{MgSO}_{4} 0.05 \mathrm{~g} / \mathrm{L}$, yeast extract $0.05 \mathrm{~g} / \mathrm{L}$, agar 15 g/L) [Kasana et al., 2008] and Modified Cellulose agar replacing carboxymethylcellulose in CMC agar with cellulose for cellulose degrading efficiency test. Mcbeth medium $\left(\mathrm{K}_{2} \mathrm{HPO}_{4} 1 \mathrm{~g} / \mathrm{L}, \mathrm{CaCO}_{3} 2 \mathrm{~g} / \mathrm{L}, \mathrm{Na}_{2} \mathrm{SO}_{4} 2 \mathrm{~g} / \mathrm{L}\right.$, $\mathrm{MgSO}_{4} .7 \mathrm{H}_{2} \mathrm{O} 1 \mathrm{~g} / \mathrm{L},\left[\left(\mathrm{NH}_{4}\right)_{2} \mathrm{SO}_{4}\right] 2 \mathrm{~g} / \mathrm{L}, \mathrm{CMC} 1.0 \%$, Agar $15 \mathrm{~g} / \mathrm{L}) ;$ Casein Starch Peptone Yeast Malt Extract (CSPY-ME) medium $\left(\mathrm{K}_{2} \mathrm{HPO}_{4} 0.5 \mathrm{~g} / \mathrm{L}\right.$, Casein $3 \mathrm{~g} / \mathrm{L}$, Maize starch $10 \mathrm{~g} / \mathrm{L}$, Peptone $1 \mathrm{~g} / \mathrm{L}$, Yeast extract $1 \mathrm{~g} / \mathrm{L}$, Malt extracts $10 \mathrm{~g} / \mathrm{L}$, Agar $15 \mathrm{~g} / \mathrm{L}$ ); Starch Casein Agar (Soluble starch $10 \mathrm{~g} / \mathrm{L}$, Casein $0.3 \mathrm{~g} / \mathrm{L}, \mathrm{K}_{2} \mathrm{HPO}_{4} 2 \mathrm{~g} / \mathrm{L}$, $\mathrm{CaCO}_{3} 0.02 \mathrm{~g} / \mathrm{L}, \mathrm{FeSO}_{4} 7 \mathrm{H}_{2} \mathrm{O} 0.01 \mathrm{~g} / \mathrm{L}, \mathrm{KNO}_{3} 2 \mathrm{~g} / \mathrm{L}$, $\mathrm{MgSO}_{4} 7 \mathrm{H}_{2} \mathrm{O} 0.05 \mathrm{~g} / \mathrm{L}, \mathrm{NaCl} 2 \mathrm{~g} / \mathrm{L}$, Agar $18 \mathrm{~g} / \mathrm{L}$ ) [Dubey and Maheshwari, 2004] and Cellulose Congo Red Agar with slight modification $\left(\mathrm{K}_{2} \mathrm{HPO}_{4} 0.50 \mathrm{~g} / \mathrm{L}, \mathrm{MgSO}_{4} 0.25\right.$ $\mathrm{g} / \mathrm{L}$, cellulose powder $1.88 \mathrm{~g} / \mathrm{L}$, Congo red $0.20 \mathrm{~g} / \mathrm{L}$, Agar $15 \mathrm{~g} / \mathrm{L}$, Gelatine $2 \mathrm{~g} / \mathrm{L}) ; \quad$ Staniers Basal broth supplemented separately with different natural cellulosic wastes viz. straw powder, wood powder and finely grated vegetable peels for estimating cellulolytic activity of the selected cellulose degrader.

\section{Isolation, purification and maintenance of isolates}

$100 \mathrm{mg}$ of the soil samples from municipal wastes were serially diluted in $10 \mathrm{~mL}$ of sterilized normal saline $(0.85$ $\%)$ and direct plating of six fold serial dilution in triplicates was done on Nutrient Agar and kept in the incubator at 37 ${ }^{\circ} \mathrm{C}$ for $48 \mathrm{~h}$. Different colonies of actinomycetes thus obtained were purified by streaking (Dubey \& Maheshwari, 2004) and maintained on Nutrient agar slants at $4{ }^{\circ} \mathrm{C}$ with periodic sub culturing.

\section{Screening of cellulose degrading microorganisms from the isolates}

Screening of cellulose degrading microorganisms was conducted by using Congo red dye. The isolates were grown on CMC Agar ( $\mathrm{pH} 7.0)$ and incubated at $37^{\circ} \mathrm{C}$ for 5 days to allow for the secretion of cellulase. The agar medium was flooded with an aqueous solution of Congo red $(1 \% \mathrm{w} / \mathrm{v})$ for $15 \mathrm{~min}$ to visualize the hydrolysis zone. The Congo red solution was then poured off and the plates were further treated by flooding with $1 \mathrm{~N} \mathrm{HCl}$ for 15 min. To indicate the cellulase activity of the organisms, diameters of clear zone around colonies on CMC agar were measured. The culture producing the largest clear zone was selected for further studies.

\section{Biochemical characterization of the selected isolate}

Culture was characterized morphologically and physiologically by Gram's staining and different biochemical tests as per Bergey's Manual of Systematic Bacteriology which included Indole, methyl red, VogesProskauer, citrate utilization test, catalase, urease, starch, gelatin hydrolysis, sugar fermentation, caseinase, hydrogen sulphide test and nitrate reduction test. Fresh culture was used for all the tests.

\section{Effects of various growth parameters on the isolate}

The influence of temperature was studied by incubation of the media at $4{ }^{\circ} \mathrm{C}, 10{ }^{\circ} \mathrm{C}, 15^{\circ} \mathrm{C}, 25^{\circ} \mathrm{C}, 30^{\circ} \mathrm{C}, 37^{\circ} \mathrm{C}, 42$ ${ }^{\circ} \mathrm{C}$ and $55^{\circ} \mathrm{C}$ for $24 \mathrm{~h}$. Similarly the influence of $\mathrm{NaCl}$ was studied using Nutrient agar with different $\mathrm{NaCl}$ concentrations (2\%, 3\%, $4 \%, 5 \%, 6 \%, 7 \%, 8 \%, 9 \%$ and $10 \%$ ) prepared by dissolving $2 \mathrm{~g}, 3 \mathrm{~g}, 4 \mathrm{~g}, 5 \mathrm{~g}, 6 \mathrm{~g}, 7$ $\mathrm{g}, 8 \mathrm{~g}, 9 \mathrm{~g}$ and $10 \mathrm{~g}$ of $\mathrm{NaCl}$ in $100 \mathrm{~mL}$ of sterilized distilled water to obtain $2 \%-10 \%$ concentration of $\mathrm{NaCl}$. The influence of $\mathrm{pH}$ was observed by adjusting $\mathrm{pH}$ of the media by using $\mathrm{pH}$ meter (Systronics) to $4.5,5.0,5.7,6.8$, 8.0, 9.0, 10.0, 11.0 and 12.0; and incubating for $24 \mathrm{~h}$. All the experiments were done in triplicates.

\section{Influence of media on growth of the isolate}

The selected strain was inoculated on the slants of CMC agar, modified Cellulose agar, Stanier's Basal medium, Mcbeth medium, Starch Casein Agar, CSPY-ME medium and Cellulose Congo Red Agar; and incubated at $37^{\circ} \mathrm{C}$ for 7 days. The cultural characteristics were observed and recorded.

\section{Influence of carbon sources on growth of the isolate}

The isolate was inoculated separately in mineral salt medium supplemented with $0.5 \%(\mathrm{w} / \mathrm{v})$ of each of the different carbohydrates as substrates that included dextrose, fructose, sucrose, lactose, mannitol, inositol, starch and cellulose. The isolate were incubated at $37^{\circ} \mathrm{C}$ for 7 days. The culture characteristics of the isolate on different carbohydrate substrates were observed and recorded.

\section{Estimation of degradation of straw powder, wood powder and finely grated vegetable peels by the isolate at different growth phases}

$10 \mathrm{~mL}$ of Stanier's Basal broth with $100 \mathrm{mg}$ of different cellulosic substrates as sole carbon source viz. Straw, 
wood and vegetables peels was prepared separately. Wood shavings and straw, powdered in the grinder, and grated vegetable peels were weighed on the Electronic balance. The broths were autoclaved and inoculated with the selected strain. The tubes were incubated in the shaker incubator at $37^{\circ} \mathrm{C}$. After the incubation period, the culture broths were filtered through previously weighed filter papers. The filter papers with the residues were dried in the hot air oven at $180{ }^{\circ} \mathrm{C}$ for $15 \mathrm{~min}$ and reweighed. The difference between the initial and the final weights gave the amount of cellulosic substrates degraded by the isolate. The observations were recorded at an interval of two days. The test was performed to compare the cellulolytic activity of the isolate on the different cellulosic substrates over a period of 8 days.

\section{RESULTS}

\section{Isolation and screening of cellulose degrading} microorganisms from the isolates

$100 \mathrm{mg}$ of the soil samples from municipal wastes were serially diluted in $10 \mathrm{~mL}$ of sterilized normal saline $(0.85$ $\%$ ) and plated on Nutrient Agar in triplicates by six fold serial dilution. The plates were incubated at $37{ }^{\circ} \mathrm{C}$ for 24-48 h. Different colonies of actinomycetes thus obtained were purified by streaking on CMC agar medium with $\mathrm{pH} 7.0$ at $37{ }^{\circ} \mathrm{C}$ for 5 days for the cellulase production. Screening of isolates was conducted by using the Congo red test as a preliminary study for identifying cellulose degraders. Since the sole carbon source in CMC agar was carboxymethylcellulose, the clear zone in the medium indicated cellulose degradation by the isolates. The culture producing the largest clear zone, as shown in Figure 1, was selected for further studies.

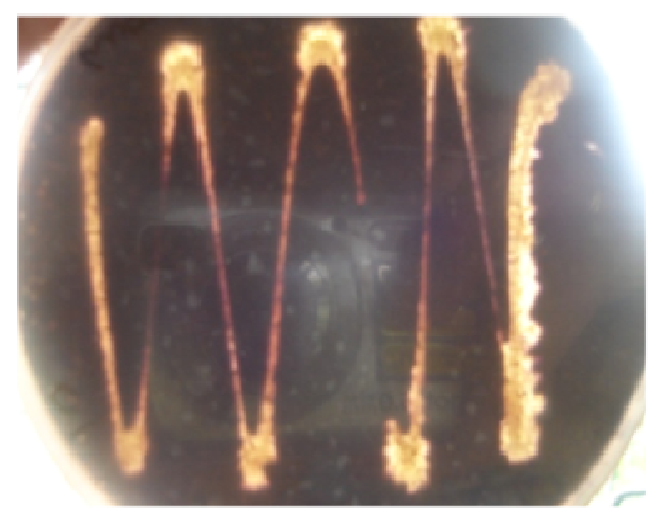

Figure 1: $S$. albospinus showing clear zone of cellulose degradation after Congo red test

\section{Morphological and biochemical characterization of the selected isolate}

The selected cellulose degrader was critically examined for its morphology. The colonies of the isolate were white and powdery. The margins were radiating with no elevations as shown in Figure 2a. Yellow to brown pigmentation was observed on the reverse side of the colonies as shown in Figure 2b. The microscopic view showed Gram-positive filaments with chains of spores in whorls (Figure 3 )
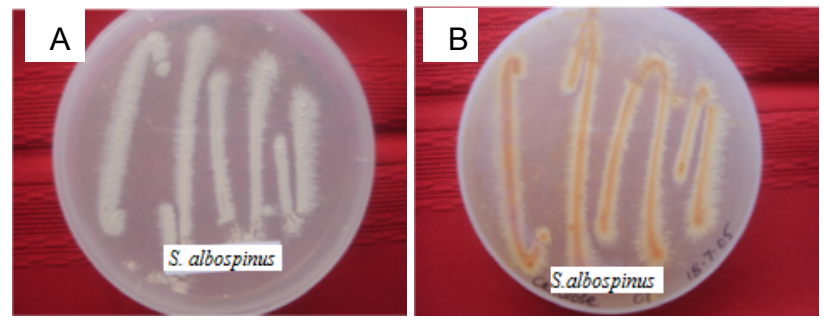

Figure 2: Colonies of $S$. albospinus (A) front view (B) reverse view

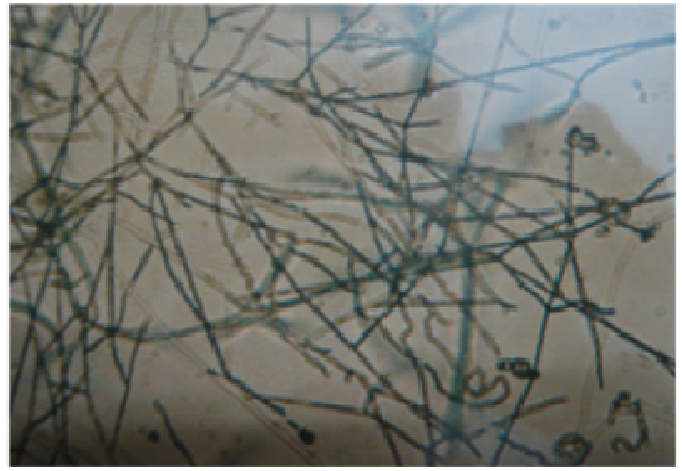

Figure 3: S. albospinus microscopic view

The biochemical tests were performed on the selected isolate and are recorded in Table 1. The isolate showed positive result for amylase test, catalase test, nitrate reduction test and negative for all the rest of the specified biochemical tests. The morphological and cultural characteristic of the isolate were compared with known Actinomycetes species described in Bergey's Manual of Determinative Bacteriology (Holt et al., 1994) and Bergey's Manual of Systematic Bacteriology, Vol. 4 (Williams et al., 1989) and was identified as Streptomyces genus. This was confirmed by Microbial Type Culture Collection and Gene Bank, Institute of Microbial Technology, Chandigarh as Streptomyces albospinus (MTCC No. 8768).

\section{Effect of various growth parameters on the isolate}

Growth parameters of the isolates were established with respect to $\mathrm{pH}$, temperature and saline tolerance. The results recorded in Table 2 showed that the strain $S$. albospinus (MTCC 8768) showed growth on a wide range of temperatures between $25{ }^{\circ} \mathrm{C}$ and $45{ }^{\circ} \mathrm{C}$, though luxuriant growth was restricted between $30{ }^{\circ} \mathrm{C}$ and $42{ }^{\circ} \mathrm{C}$. The strain showed growth at all $\mathrm{NaCl}$ concentrations $(2 \%$ $-9 \%$ ), except $10 \%$ and it showed growth at all the tested $\mathrm{pH}$ in the range from 5.7 to 11.0, the optimum being between $\mathrm{pH} 5.7$ and 6.8. Hence the strain proves to be slightly acidophilic to neutral. 
Table 1: Biochemical characteristics of strain $S$. Influence of media on growth of the isolate albospinus (MTCC No. 8768)

\begin{tabular}{ll} 
Biochemical test & S. albospinus \\
\hline Cultural characteristics & White powdery colony \\
Gram stain & + \\
Shape & Filamentous \\
Amylase test & + \\
Caseinase test & - \\
Catalase test & + \\
Citrate utilization test & - \\
Fermentation of & - \\
carbohydrates & - \\
Gelatinase test & - \\
Hydrogen sulphide test & - \\
Indole test & - \\
Methyl Red test & - \\
Nitrate reduction test & + \\
Urease test & - \\
Voges-Preskauer test & - \\
\hline \multicolumn{1}{c}{ +: Positive reaction; $-:$ Negative reaction }
\end{tabular}

The culture characteristics of the strain $S$. albospinus (MTCC 8768) listed in Table 3 showed luxuriant to moderate growth on most media tested except Casein Starch Peptone Yeast Malt Extract (CSPY-ME) on which the growth was poor. The colour of colony in all the tested media was white except Cellulose agar and CSPY-ME on which it was dirty white. The texture of the colony was powdery in all media used except SCA and CSPY-ME on which it was dry. No pigmentation was observed in any of the tested media.

\section{Influence of carbon sources on growth of the isolates}

The culture characteristics of the strain $S$. albospinus (MTCC 8768) shown in Table 4 indicated that the strain was capable of utilizing all tested carbon sources except lactose. The aerial mycelium was white and the texture powdery on all carbon sources used. The substrate mycelium was peach coloured in all the carbon sources except lactose, starch and cellulose. No soluble pigment

Table 2: Cultural characteristics of strain S. albospinus (MTCC No. 8768) on different temperature, $\mathrm{NaCl}$ concentration and $\mathrm{pH}$

\begin{tabular}{|c|c|c|c|c|c|}
\hline 仓ำ & 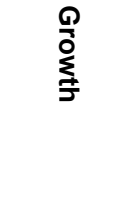 & 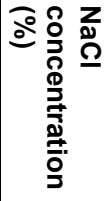 & $\begin{array}{l}\stackrel{0}{0} \\
\frac{1}{2} \\
\frac{1}{5}\end{array}$ & 후 & 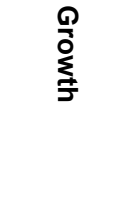 \\
\hline 4 & Nil & 2.0 & Poor & 4.5 & $\mathrm{Nil}$ \\
\hline 10 & Nil & 3.0 & Poor & 5.0 & Nil \\
\hline 15 & Nil & 4.0 & Poor & 5.7 & Luxuriant \\
\hline 25 & Poor & 5.0 & Moderate & 6.8 & Luxuriant \\
\hline 30 & Moderate & 6.0 & Moderate & 8.0 & Moderate \\
\hline 37 & Luxuriant & 7.0 & Moderate & 9.0 & Moderate \\
\hline 42 & Luxuriant & 8.0 & Moderate & 10.0 & Poor \\
\hline 45 & Moderate & 9.0 & Poor & 11.0 & Poor \\
\hline 55 & Nil & 10.0 & Nil & 12.0 & Nil \\
\hline
\end{tabular}

Table 3: Culture characteristics of the strain S.albospinus (MTCC No. 8768) on media

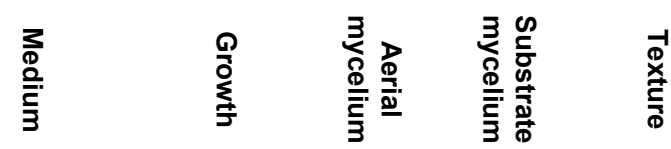

\begin{tabular}{|c|c|c|c|c|}
\hline CMC agar & Luxuriant & White & White & Powdery \\
\hline Cellulose agar & Luxuriant & $\begin{array}{l}\text { Dirty } \\
\text { white }\end{array}$ & White & Slimy \\
\hline $\begin{array}{c}\text { Stanier's } \\
\text { Basal agar }\end{array}$ & Luxuriant & White & White & Powdery \\
\hline Mcbeth agar & Luxuriant & White & White & Powdery \\
\hline $\begin{array}{c}\text { Starch casein } \\
\text { agar }\end{array}$ & Moderate & White & White & Dry \\
\hline $\begin{array}{l}\text { CSPY-ME } \\
\text { agar }\end{array}$ & Poor & $\begin{array}{l}\text { Dirty } \\
\text { white }\end{array}$ & White & Dry \\
\hline $\begin{array}{c}\text { Cellulose } \\
\text { Congo Red } \\
\text { Agar }\end{array}$ & Luxuriant & White & White & Powdery \\
\hline
\end{tabular}

Estimation of degradation of straw powder, wood powder and finely grated vegetable peels by the isolate at different growth phases

$10 \mathrm{~mL}$ of the Stanier's Basal broth was dispensed in five tubes and $100 \mathrm{mg}$ of straw powder was added as sole carbon source in each tube. The tubes were autoclaved and inoculated with the strain S. albospinus (MTCC 8768) and kept in the shaker incubator for a period of 8 days at $37^{\circ} \mathrm{C}$. On the $2^{\text {nd }}$ day, one of the tubes was taken out from the shaker incubator and the culture broth was filtered through a previously weighed filter paper. The filter paper with the residue was dried in the oven at 180 ${ }^{\circ} \mathrm{C}$ for $15 \mathrm{~min}$ and re-weighed. The difference between the initial and the final weights gave the amount of straw powder degraded by the isolate in 2 days. The process was repeated on the $4^{\text {th }}, 6^{\text {th }}$ and $8^{\text {th }}$ day and the cellulolytic potential of the isolate was estimated. The carbon source in the Stanier's Basal broth was substituted with wood powder and finely grated vegetable peels separately to estimate the cellulolytic potential of the Streptomyces strain by the similar procedure as described above. From the data collected, it was observed that the degradation of all the substrates increased initially and then became constant from the $6^{\text {th }}$ day onwards, also, the degradation of the grated vegetable peels was maximum $(64 \mathrm{mg})$ followed by the straw powder $(38 \mathrm{mg})$ and wood powder (28 mg) as shown in Table 4

\section{DISCUSSION}

A large proportion of vegetation added to soil is cellulose; therefore, decomposition of cellulose has a special significance in the biological cycle of carbon (Lederberg, 1992). A wide variety of bacteria are known for their production of hydrolytic enzymes with streptomycetes 
Table 4: Estimation of degradation of selected cellulosic materials by $S$. albospinus (MTCC No. 8768) over a period of 8 days

\begin{tabular}{|c|c|c|c|c|c|}
\hline $\begin{array}{l}\text { Cellulosic } \\
\text { substrate }\end{array}$ & & $\begin{array}{l}2^{\text {nd }} \\
\text { day }\end{array}$ & $\begin{array}{l}4^{\text {th }} \\
\text { day }\end{array}$ & $\begin{array}{l}6^{\text {th }} \\
\text { day }\end{array}$ & $\begin{array}{l}8^{\text {th }} \\
\text { day }\end{array}$ \\
\hline \multirow[b]{2}{*}{$\begin{array}{c}\text { Straw } \\
\text { powder }\end{array}$} & $\begin{array}{l}\text { Amount of } \\
\text { substrate } \\
\text { consumed } \\
\text { (in } \mathrm{mg} \text { ) } \\
\end{array}$ & 34 & 38 & 38 & 38 \\
\hline & $\begin{array}{l}\text { Amount of } \\
\text { cellulosic } \\
\text { biomass } \\
\text { obtained (in } \\
\text { mg) }\end{array}$ & 66 & 62 & 62 & 62 \\
\hline \multirow[b]{2}{*}{$\begin{array}{l}\text { Wood } \\
\text { powder }\end{array}$} & $\begin{array}{l}\text { Amount of } \\
\text { substrate } \\
\text { consumed } \\
\text { (in } \mathrm{mg} \text { ) }\end{array}$ & 24 & 24 & 28 & 28 \\
\hline & $\begin{array}{l}\text { Amount of } \\
\text { cellulosic } \\
\text { biomass } \\
\text { obtained (in } \\
\text { mg) }\end{array}$ & 76 & 76 & 72 & 72 \\
\hline \multirow{2}{*}{$\begin{array}{c}\text { Grated } \\
\text { vegetable } \\
\text { peels }\end{array}$} & $\begin{array}{l}\text { Amount of } \\
\text { substrate } \\
\text { consumed } \\
\text { (in } \mathrm{mg} \text { ) }\end{array}$ & 58 & 60 & 64 & 64 \\
\hline & $\begin{array}{l}\text { Amount of } \\
\text { cellulosic } \\
\text { biomass } \\
\text { obtained (in } \\
\text { mg) }\end{array}$ & 42 & 40 & 36 & 36 \\
\hline
\end{tabular}

being the best known enzyme producers (Vinogradova and Kushnir, 2003). The present study was an investigation into the isolation and characterization of cellulolytic bacteria and actinomycetes and their potential role in biomass utilization. In this investigation, $S$. albospinus (MTCC No. 8768), isolated from the municipal wastes, and was used to observe the cellulose degradation activity on different natural cellulosic substrates at an interval of two days. It was found that initially there was a gradual increase in the degradation of the cellulosic substrates by the isolate and thereafter a static condition was registered in which no further cellulose degradation occurred. This may be explained by the work of Van Dycke (1972), who reported that the end product acts as inhibitor to the process of cellulose hydrolysis and the decline in hydrolysis are the early removal of more assessable amorphous cellulose, resulting in an increase in the proportion of more resistant crystalline cellulose and the denaturation of adsorbed cellulases (Howell and Mangat, 1978). As shown in Table4, the straw powder degradation was $34 \mathrm{mg}$ in two days which increased to $38 \mathrm{mg}$ and then no further degradation took place. Similarly, there was $24 \mathrm{mg}$ degradation of wood powder which increased to $28 \mathrm{mg}$ on $6^{\text {th }}$ day and remained constant; whereas grated vegetable peels degraded to $58 \mathrm{mg}, 60 \mathrm{mg}$ and $64 \mathrm{mg}$ on $2^{\text {nd }}, 4^{\text {th }}$ and $6^{\text {th }}$ day and remained constant onwards. It was found that the isolate showed maximum cellulolytic activity against grated vegetable peels followed by straw powder and then wood powder. According to Beltrame et. al (1984), the ability of cellulolytic microorganisms to degrade cellulose vary greatly with the physico-chemical characteristics of the substrate and the crystallinity degree of cellulose is one of the most important structural parameters which affects the rate of enzymatic degradation by hydrolysis (Petre et al., 1999).

\section{CONCLUSION}

The present study revealed cellulolytic activities of $S$. albospinus (MTCC No. 8768) as it could degrade not only the cellulose rich culture media but also the naturally occurring cellulosic materials selected for our investigation. It can, therefore, be concluded that by optimising the $\mathrm{pH}$ and the temperature, its potential can be utilized to biodegrade the low cost enormous stock of cellulose in nature and the end product may be useful in the preparation of a number of chemicals including bioethanol.

\section{ACKNOWLEDGEMENTS}

This study was carried out at the Department of Industrial Microbiology, Patna Women's College, Patna University, Patna and the authors thank Dr. (Sister) Doris D'Souza, A.C., Principal, Patna Women's College for encouragement and providing necessary infrastructural facilities.

\section{REFERENCES}

Beltrame, P.L., Carnitti, P., Focher, B. (1984). Enzymatic hydrolysis of cellulosic materials: a kinetic study. Biotechnology and Bioengineering. 31:160167.

Dubey, R.C., Maheshwari, D.K. (2004). Practical Microbiology, S. Chand \& Company Ltd., New Delhi. pp 352.

Gautam S. P., Bundela P. S., Pandey A. K., Jamaluddin, Awasthi M. K. and Sarsaiya S. (2010). Cellulase production by Pseudomonas sp. Isolated from municipal solid waste compost. International Journal of Academic Research 2(6): 329-332

Gautam, S. P., Bundela, P. S., Pandey, A. K., Khan, J., Awasthi, M. K. and Sarsaiya, S. (2011). Optimization for the Production of Cellulase Enzyme from Municipal Solid Waste Residue by Two Novel Cellulolytic Fungi. Biotechnology Research International 2011: 1-8

Hao, X. C., Yu, X.B. and Yan, Z. L. (2006). Production of cellulase by Trichoderma reesei wx-112, Food Technology Biotechnology 44 (1) 89-94.

Holt, J. G., Krieg, N. R., Sheath, P. H.A., Sterley, J. T. and Williams S.T. (1994). Bergey's Manual of Determinative Bacteriology. Ninth Ed. Williams and Wilkins. Maryland, USA.

Howell, J.A. and Mangat, M. (1978). Enzyme 
deactivation during cellulose hydrolysis. Biotechnology and Bioengineering 20: 847-863.

Kasana, R.C., Salwan, R., Dhar, H., Dutt, S. and Gulati, A. (2008). A rapid and easy method for the detection of microbial cellulases on agar plates using Gram's iodine. Current Microbiology 57: 503-507.

Lederberg, J. (1992). Cellulases. In: Encyclopaedia of Microbiology (Vol. 1; A-C). Academic Press, Inc.

Lynd, Lee R., Paul J., Willem H. V. Z., and Isak S. P. (2002). Microbiology and molecular biology reviews, pp. 506-577.

Obuekwe, C.C., and Okungbowa, J.O. (1986). Assessment of biomass production potential of some fungal isolates. Nigerian Journal of Scientific and Industrial Research 66 (1-2): 120-130

Petre, M., Zarnea, G., Adrian,P. and Gheorghiu, E. (1999). Biodegradation and bioconversion of cellulose wastes using bacterial and fungal cells immobilized in radio polymerized hydrogels. Resources, Conservation and Recycling 27:309-332.

Vinogradova, S. P. and Kushnir S. N. (2003). Biosynthesis of hydrolytic enzymes during cocultivation of macro- and micromycetes. Applied Biochemistry and Microbiology 39: 573-575.

Williams, S. T., Sharpe, E. M. and Holt, J. G. (1989). Bergey's Manual of Systematic Bacteriology. First Edition. Volume 4: Actinomycetes. Williams \& Wilkins, Baltimore, MD. 